\title{
Evaluation of Fungicides, Botanical and Organic Amendments for Management of Chilli Powdery Mildew caused by Leveillula taurica (Lev.) Arn
}

\author{
Deepak Kumar Saini", R. N. Bunker, Poonam Yadav, Sakshi Meena and Lalita Sharma
}

Department of Plant Pathology, Rajasthan College of Agriculture, Maharana Pratap University of Agriculture and Technology, Udaipur, Rajasthan (India)

*Corresponding author

\section{A B S T R A C T}

\section{Keywords}

Leveillula taurica,

Fungicides,

Botanicals, Organic amendments,

Management

Article Info

Accepted:

26 September 2020

Available Online:

10 October 2020

\begin{abstract}
Powdery mildew of chilli caused by Leveillula taurica is one of the devastating diseases of chilli. The present studies were aimed of evaluation of promising fungicides, botanical and organic amendments for the management of powdery mildew of chilli under field conditions during kharif2018. Among the eight treatments, combination of Propiconazole $0.1 \%+$ Neem oil $5 \%$ was found most effective for the management of powdery mildew with minimum per cent disease index (PDI) $14.73 \%$ and maximum78.95 per cent disease control (PEDC) with maximum fresh chilli fruit yield of $(40.66 \mathrm{q} / \mathrm{ha})$ in epiphytotic condition followed by Myclobutanil $0.1 \%$ + Neem oil 5\% (17.53 PDI) with 74.91 PEDC, with fruit yield of $(36.29 \mathrm{q} / \mathrm{ha})$ was recorded over untreated control. The aim of present study was to find out an innovative and environmentally safe strategy for the control of powdery mildew in chilli by integrating of chemical fungicides, Botanicals and organic amendments. The developed integrated disease management is a package that would lower the disease incidence and increase the yield
\end{abstract}

\section{Introduction}

Chilli (Capsicum annum L. and C. fruitcense) is an important commercial horticulture crop and grown for the domestic market and export purpose. It is believed to be originated from South America during $15^{\text {th }}$ Century (Pickersgill, 1997). During this century Portuguese introduced chilli crop to India from Brazil. The major chilli producer and exporter countries in the world are China, India, Mexico, Morocco, Pakistan, Thailand and Turkey (Lakshmi et al., 2014). India is the world's largest consumer, producer and exporter of chilli and contributes about 25 percent of total world production (Chandra Nayaka et al., 2009) with the 4 per cent share of total export in the world (Gutpa and Naik, 2005). Chilli suffers from many diseases caused by fungi, bacteria, viruses and nematodes. Among the fungal diseases, powdery mildew, leaf spot and anthracnose or fruit rot are the most prevalent ones (Khodke et al., 2009). The powdery mildew caused by 
Leveillula taurica (Lev.) Arn. is a major constraint in chilli production in India causing heavy yield loss ranging from 14 to $30 \%$, due to severe defoliation and reduction in photosynthesis, size and number of fruits per plant (Mathur et al., 1972; Sivaprakasam et al., 1976; Gohokar and Peshney, 1981). In India, powdery mildew of chilli occurs in endemic form on a severe scale and has become a major constraint to chilli production (Singh and Lodha, 1985).

Many systemic and non-systemic fungicides were reported to manage the powdery mildew of capsicum. The information on the efficacy of new fungicides against powdery mildew of capsicum is insufficient. By considering the seriousness of disease and the economic damage/exorbitant losses caused by the disease, the present investigation was carried out by using integrated management approach using new molecule fungicides, botanicals and organic amendments for their efficacy to suppress powdery mildew of chilli under field condition.

\section{Materials and Methods}

The experiment was conducted at Agronomy farm of Rajasthan College of Agriculture, MPUAT, Udaipur. The experiment was laid out to comprises 8 treatments for their efficacy over control viz., Foliar spray of Propiconazole $25 \%$ EC $(0.1 \%)$, Myclobutanil $10 \%$ WP (0.1\%), Neem oil (5\%), Panchgavya (10\%), Propiconazole 25\% EC $(0.1 \%)+$ Neem oil (5\%), Neem oil (5\%) + Panchgavya (10\%), Myclobutanil 10\% WP $(0.1 \%)+$ Neem oil $(5 \%)$ and untreated control. The chilli hybrid variety 'PusaJwala' was raised in nursery and after 25days seedling were transplanted in $1.8 \times 2.25 \mathrm{~m}^{2}$ size plots at $60 \times 45 \mathrm{~cm}$ distance having three replications in randomized block design (RBD).Powdery mildew is an obligate pathogen and it was appearing in severe condition in this region during kharif season year after year on susceptible chilli cultivar 'PusaJwala' and there was no need to develop disease by means of other methods.

The calculated quantities of different treatments (fungicides, botanicals and organic amendments) were suspended in water and applied thrice as foliar spray at 15 days' intervals from the initiation of powdery mildew symptoms. The observation of disease development and disease severity was recorded on a standard 0-5 disease rating scale (Tajider et al., 1994). After 15 days of each spray per cent disease index was calculated by the formula given by $\mathrm{Mc}$ Kinney (1923) and Wheeler (1969).

$$
\text { Per cent disease index }=\frac{\text { Sum of all numerical rating }}{\text { No. of plants } x \text { Maximum rating }} \times 100
$$

The per cent efficacy of disease control (PEDC) was calculated by using following formula.

$$
\mathrm{PEDC}=\frac{\text { PDI in control }-\mathrm{PDI} \text { in treatment }}{\text { PDI in control }} \times 100
$$

\section{Results and Discussion}

The result of the field experiment indicated that all the treatments significantly reduced the disease compared to the unsprayed control after each spray. Among eight treatments combination of (Propiconazole $0.1 \%+$ Neem oil 5\%) was found most effective to suppress the powdery mildew of chilli at each spray. Powdery mildew intensity (PDI) during in this treatment continuously decreased (25.47; 16.93 and14.73 per cent) with maximum percent disease control (53.11; 73.45 and 78.95 per cent) and highest yield $40.66 \mathrm{q} / \mathrm{hac}$ from the first to last spray which was significantly superior over all the treatments over control (Fig. 1; Table 1 and 2). 
Table.1 Powdery mildew of chilli 0-5 disease rating scale (Tajider et al., 1994)

\begin{tabular}{|l|l|}
\hline Score & Description \\
\hline $\mathbf{0}$ & No infection \\
\hline $\mathbf{1}$ & $1-10 \%$ leaf area infected \\
\hline $\mathbf{2}$ & $10.1-15 \%$ leaf area infected \\
\hline $\mathbf{3}$ & $15.1-25 \%$ leaf area infected \\
\hline $\mathbf{4}$ & $25.1-50 \%$ leaf area infected \\
\hline $\mathbf{5}$ & $>50 \%$ of leaf area infected \\
\hline
\end{tabular}

Table.2 Evaluation of promising fungicides, botanical and organic amendments for suppression of powdery mildew of chilli under field condition

\begin{tabular}{|c|c|c|c|c|c|c|c|c|c|c|}
\hline $\begin{array}{l}\text { Tr. } \\
\text { No. }\end{array}$ & Treatment & $\begin{array}{l}\text { *PDI at 1st } \\
\text { Appearance }\end{array}$ & $\begin{array}{c}\text { PDI at } \\
15 \\
\text { days } \\
\text { after } \\
1 \text { st } \\
\text { spray }\end{array}$ & **PEDC & $\begin{array}{c}\text { PDI at } \\
15 \\
\text { days } \\
\text { after } \\
\text { 2nd } \\
\text { spray }\end{array}$ & PEDC & $\begin{array}{c}\text { PDI at } \\
15 \\
\text { days } \\
\text { after } \\
\text { 3rd } \\
\text { spray }\end{array}$ & PEDC & $\begin{array}{l}* * * \text { Yield } \\
\text { (Kg/plot) }\end{array}$ & $\begin{array}{c}* * * \text { Yield } \\
(\mathbf{q} / \mathbf{h a})\end{array}$ \\
\hline $\mathbf{T}_{1}$ & $\begin{array}{c}\text { Propiconazole } \\
0.1 \%\end{array}$ & $\begin{array}{c}10.53 \\
(18.92)\end{array}$ & $\begin{array}{c}31.60 \\
(34.19)\end{array}$ & $\begin{array}{c}41.88 \\
(40.30)\end{array}$ & $\begin{array}{c}23.80 \\
(29.18)\end{array}$ & $\begin{array}{c}62.58 \\
(52.27)\end{array}$ & $\begin{array}{c}20.07 \\
(26.59)\end{array}$ & $\begin{array}{c}71.24 \\
(57.56)\end{array}$ & 1.34 & 33.00 \\
\hline $\mathbf{T}_{2}$ & $\begin{array}{c}\text { Myclobutanil } \\
0.1 \%\end{array}$ & $\begin{array}{c}10.93 \\
(19.29)\end{array}$ & $\begin{array}{c}34.40 \\
(35.90)\end{array}$ & $\begin{array}{c}36.75 \\
(37.28)\end{array}$ & $\begin{array}{c}26.80 \\
(31.16)\end{array}$ & $\begin{array}{c}57.80 \\
(49.50)\end{array}$ & $\begin{array}{c}23.00 \\
(28.63)\end{array}$ & $\begin{array}{c}67.06 \\
(54.97)\end{array}$ & 1.22 & 30.04 \\
\hline $\mathbf{T}_{3}$ & Neem oil $5 \%$ & $\begin{array}{c}11.60 \\
(19.85)\end{array}$ & $\begin{array}{c}39.20 \\
(38.74)\end{array}$ & $\begin{array}{c}27.80 \\
(31.67)\end{array}$ & $\begin{array}{c}33.27 \\
(35.21)\end{array}$ & $\begin{array}{c}47.62 \\
(43.62)\end{array}$ & $\begin{array}{c}28.87 \\
(32.48)\end{array}$ & $\begin{array}{c}58.68 \\
(49.98)\end{array}$ & 1.00 & 24.61 \\
\hline $\mathbf{T}_{4}$ & $\begin{array}{c}\text { Panchgavya } \\
10 \%\end{array}$ & $\begin{array}{c}9.91 \\
(18.34)\end{array}$ & $\begin{array}{c}42.00 \\
(40.38)\end{array}$ & $\begin{array}{c}22.80 \\
(28.44)\end{array}$ & $\begin{array}{c}37.07 \\
(37.48)\end{array}$ & $\begin{array}{c}41.53 \\
(40.07)\end{array}$ & $\begin{array}{c}31.67 \\
(34.22)\end{array}$ & $\begin{array}{c}54.73 \\
(47.70)\end{array}$ & 0.86 & 21.15 \\
\hline$T_{5}$ & $\begin{array}{c}\text { Propiconazole } \\
0.1 \%+\text { Neem } \\
\text { oil } 5 \%\end{array}$ & $\begin{array}{c}8.40 \\
16.839\end{array}$ & $\begin{array}{c}25.47 \\
(30.29)\end{array}$ & $\begin{array}{c}53.11 \\
(46.77)\end{array}$ & $\begin{array}{c}16.93 \\
(24.25)\end{array}$ & $\begin{array}{c}73.45 \\
(58.98)\end{array}$ & $\begin{array}{c}14.73 \\
(22.50)\end{array}$ & $\begin{array}{c}78.95 \\
(62.72)\end{array}$ & 1.65 & 40.66 \\
\hline $\mathbf{T}_{6}$ & $\begin{array}{c}\text { Neem oil } 5 \% \\
+ \text { Panchgavya } \\
10 \%\end{array}$ & $\begin{array}{c}9.33 \\
(17.76)\end{array}$ & $\begin{array}{c}36.87 \\
(37.36)\end{array}$ & $\begin{array}{c}32.01 \\
(34.29)\end{array}$ & $\begin{array}{c}30.20 \\
(33.32)\end{array}$ & $\begin{array}{c}52.79 \\
(46.58)\end{array}$ & $\begin{array}{c}25.80 \\
(30.50)\end{array}$ & $\begin{array}{c}63.08 \\
(52.57)\end{array}$ & 1.09 & 26.91 \\
\hline $\mathbf{T}_{7}$ & $\begin{array}{c}\text { Myclobutanil } \\
0.1 \%+\text { Neem } \\
\text { oil } 5 \%\end{array}$ & $\begin{array}{c}9.87 \\
(18.28)\end{array}$ & $\begin{array}{c}28.93 \\
(32.52)\end{array}$ & $\begin{array}{c}46.72 \\
(43.09)\end{array}$ & $\begin{array}{c}20.40 \\
(26.79)\end{array}$ & $\begin{array}{c}67.79 \\
(55.46)\end{array}$ & $\begin{array}{c}17.53 \\
(24.74)\end{array}$ & $\begin{array}{c}74.91 \\
(59.91)\end{array}$ & 1.47 & 36.29 \\
\hline $\mathbf{T}_{8}$ & Control & $\begin{array}{c}10.80 \\
(19.18)\end{array}$ & $\begin{array}{c}54.53 \\
(47.59)\end{array}$ & 0 & $\begin{array}{c}63.60 \\
(52.88)\end{array}$ & 0 & $\begin{array}{c}69.87 \\
(56.69)\end{array}$ & 0 & 0.65 & 16.13 \\
\hline & SEm \pm & 0.534 & 0.629 & 1.048 & 0.822 & 1.144 & 0.773 & 0.980 & 0.024 & 0.589 \\
\hline & $\mathrm{CD}(P=0.05)$ & 1.634 & 1.927 & 3.211 & 2.517 & 3.505 & 2.366 & 3.002 & 0.073 & 1.805 \\
\hline
\end{tabular}

*Per cent disease index; ** Per cent efficacy of disease control; Mean of three replications; Figures given in parentheses are arcsine $\sqrt{ }$ Per cent angular transformed values. ${ }^{* * *}$ Figures in parentheses are angular transformed values 
Fig.1 Per cent disease index of promising fungicides, botanicals and organic amendments against powdery mildew of chilli under field conditions

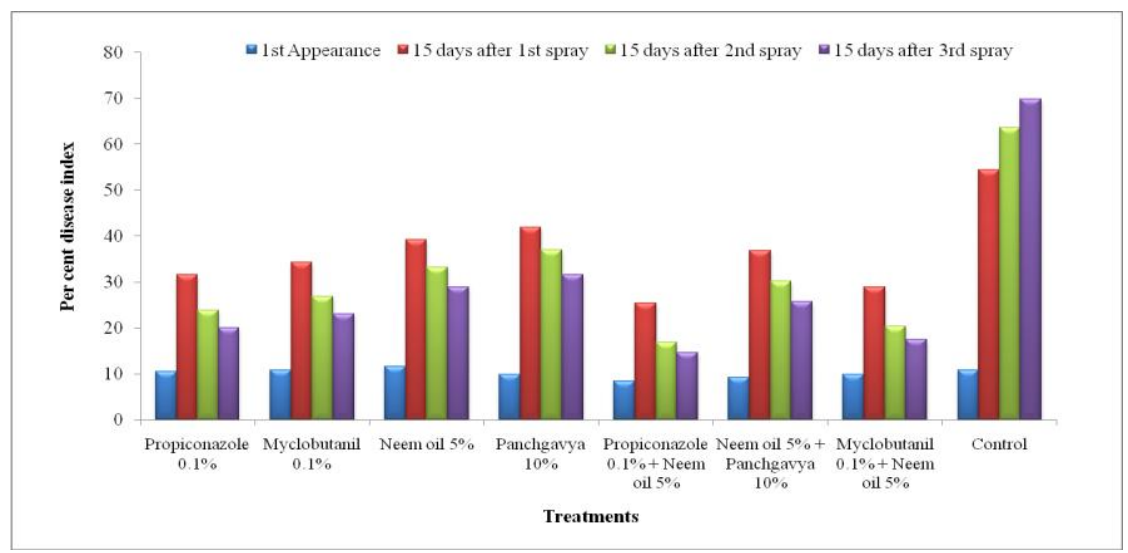

Similarly, followed by Myclobutanil $0.1 \%+$ Neem oil $5 \%$ was showed $(28.93 ; 20.40$ and 17.53 PDI) powdery mildew intensity and (46.72; 67.79 and 74.91 PEDC) per cent disease control with yield 36.29 q/hac after each spray respectively, followed by Propiconazole $0.1 \%$ was showed (31.60; 23.80 and 20.07 PDI) percent disease intensity and (41.88; 62.58, 71.24 PEDC) per cent disease control with yield $33.00 \mathrm{q} / \mathrm{hac}$ after each spray followed by Myclobutanil $0.1 \%$ (34.40; 26.80 and $23.0 \mathrm{PDI})$ per cent disease intensity and (36.75; 57.80 and 67.06 PEDC) per cent disease control with yield 30.04 q/ hac after each spray, followed by Neem oil 5\% + Panchgavya 10\% (36.87; 30.20 and 25.80 PDI) per cent disease intensity and (32.01; 52.79 and 63.08 PEDC) per cent disease control with yield 26.91 q/hac after each spray followed by Neem oil 5 $\%$ (39.20; 33.27 and 28.87 PDI) per cent disease intensity and (27.80; 47.62 and 58.68 PEDC) per cent disease control with yield $24.61 \mathrm{q} / \mathrm{hac}$ after each spray, followed by Panchgavya $10 \%$ (42.00; 37.07 and 31.67 PDI) per cent disease intensity and (22.80; 41.53 and 54.73 PEDC) per cent disease control with yield $21.15 \mathrm{q} /$ hac after each spray, respectively. The maximum per cent disease index was observed in untreated control (54.53; 63.60 and $69.87 \mathrm{PDI})$ and 0 per cent disease control (PEDC) with 16.13 q/hac.

The similar results were recorded by Raju et al., (2017) that the Propiconazole at $0.1 \%$ was found superior and highly effective with minimum PDI (9.64) and maximum yield (98.00 q/ha), against powdery mildew compare to Myclobutanil, Hexaconazole, Azoxystrobin and Wettablesulphurat $(0.1 \%)$ concentration. He reported that rest fungicides viz., Myclobutanil (11.90), Tridemefon (13.03) and Hexaconazole (15.86) with yields (94.62, 92.33, and $92.15 \mathrm{q} / \mathrm{ha}$ ) also found effective. The similar result also described by Daundeet al., 2018 that Propiconazole 0.1\% was very effective to management of powdery mildew with (9.01 PDI) with 88.0 disease control and $36.13 \mathrm{q} / \mathrm{ha}$ yield followed by Myclobutanil $0.1 \%$ (13.24 PDI) with 82.36 and yield (34.56 q/ha).

In botanical Similar result described by Peshaman et al., (2017) that neem recorded significantly lowest mean disease incidence (18.88\%), followed by Garlic (18.99\%) and Ghaneri (20.44\%), Turmeric powder (21.55), Nirgudi (22.22\%), Tulsi (22.74\%), and Parthenium $(23.06 \%)$ compared to control $(51.33 \%)$. 
In organic amendments similar results were described by Ashlesha and Paul (2014) that the Panchgavya (10\%) was effective against anthracnose of chilli with disease severity $(20.08 \%)$ and 70.46 per cent disease control, followed by Buttermilk (10\%) disease severity $(24.20 \%)$ with 64.39 per cent disaese control and Vermiwash (10\%) disease severity $(24.84 \%)$ with 63.45 per cent disease control recorded.

\section{References}

Ashlesha and Paul, Y.S. 2014. Antifungal bio efficacy of organic inputs against fungal pathogens of bell pepper. Indian journal of research. 3(6): 4-9.

Chandra Nayaka, S., Uday Shankar, A.C., Niranjana, S.R., Prakash, H.S. and Mortensen, C.N. 2009. Anthracnose disease of chilli pepper. Tech. Bull, pp.1-14.

Daunde, A.T., Khandare, V.S. and Wadikar, R.N. 2018. Management of chilli powdery mildew caused by Leveillulataurica (Lev.) Arn. using fungicides. International Journal of Current Microbiology and Applied Sciences. 6: 388-392.

Gupta, S.N. and Naik, K.B. 2005. Capsicum and chilli. Instant horticulture. pp. 8788 by Jain Brothers, New Delhi.

Gohokar, R.T. and Peshney, N.L. 1981. Chemical control of powdery mildew of chilli. Indian Journal of Agricultural Sciences. 51: 663-665.

Khodke, S.W., R.S. Gawde, and Wankhade, R.S., 2009. Management of foliar diseases of chilli. Pestology, 33: 1517.

Lakshmi, S.U., Sri Deepthi, R. PeddaKasim., D, Suneetha and P. Krishna M.S.R. 2014. Anthracnose, a prevalent disease in capsicum. Research Journal of Pharmaceutical, Biological and Chemical Sciences. 5:1583-1604.
Mathur, R.L., G. Singh, and Gupta, R.B.L. 1972. Chemical control of powdery mildew of chilli (Capsicum annum) caused by Leveillulataurica. Paper presented in the first disease on plant disease problems of Rajasthan in Dec16-17. Udaipur.

Mc Kinney, H.N. 1923. Influence of soil temperature and moisture on infection of wheat seedlings by Helminthosporiumsativam. Journal of agricultural research. 26: 195-217.

Peshaman, M.H., Dadke, M.S., Ahamed, B.Z. 2017. Effect of botanicals in management of powdery mildew of chilli pathogen Leveillulataurica. International Journal of Current Microbiology and Applied Sciences. 6(12): 1929-1935.

Pickersgill, B. 1997. Genetic resources and breeding of Capsicum spp. Euphytica. 96(1): 129-133.

Raju, J., Adivappar, N. and Jayalakshmi, K. 2017. Management of powdery mildew of capsicum under protected cultivation. International Journal of Chemical Studie. 5(5): 1213-1215.

Singh, S. and Lodha, S. 1985. Varietal reaction and evaluation of fungicides in vitro and in vivo against powdery mildew of chilli. Indian Journal of Agricultural Sciences. 55: 85-87.

Sivaprakasam, K., Jaganathan, R., Pillayarsamy, K., and Anavaradham, 1976. Control of powdery mildew of chillies. Madras Agric. J., 63: 52-54.

Tajider, S., Munshi, G.D., Rewal, H.S. 1994. Fungicidal control of grape powdery mildews. Plant Disease Research. 9. 56-57.

Wheeler, B.E.J. 1969. An introduction to plant disease. John Wiley Sons Limited, London. Pp. 331. 


\section{How to cite this article:}

Deepak Kumar Saini, R. N. Bunker, Poonam Yadav, Sakshi Meena and Lalita Sharma 2020. Evaluation of Fungicides, Botanical and Organic Amendments for Management of Chilli Powdery Mildew caused by Leveillula taurica (Lev.) Arn. Int.J.Curr.Microbiol.App.Sci. 9(10): 3542-3547. doi: https://doi.org/10.20546/ijcmas.2020.910.408 